\title{
Studying Gardens of the World with Students of Higher Education Establishments
}

\author{
Turchynova Ganna \\ Candidate of Pedagogic Sciences, Associate Professor \\ Dragomanov National Pedagogical University \\ Pet'ko Lyudmila \\ Candidate of Pedagogic Sciences, Associate Professor \\ Dragomanov National Pedagogical University \\ Holovko Tamila \\ Student of Faculty of Science Education and Ecology \\ Dragomanov National Pedagogical University (Ukraine, Kyiv) \\ We all have within us a need to create beauty. \\ And we all can in a garden, however small. \\ It is this need which has written the history of gardens. \\ Audrey Hepburn
}

\begin{abstract}
The image of one of the greatest actresses, Audrey Hepburn, is presented in different ways: actress, model, dancer, the Goodwill Ambassador for UNICEF. Audrey Hepburn, who loved nature and gardens, saw a rare opportunity to bring forth their beauty in poetic and meaningful ways in Gardens of the World. Her unique vision of the series included fusing the historical and aesthetic aspects with the arts of literature, music and painting.

Gardens of the World was filmed on location around the world, including:- Claude Monet s garden at Giverny; George Washington s Estate at Mount Vernon; the ancient moss temple garden Saiho-ji in Kyoto Japan; gardens at Mottisfont Abbey, Tintinhull House, Chilcombe Garden, Hidcote Bartram Village and Hidcote Manor in England; the Keukenhof Garden and the Tulip Fields of Lisse in the Netherlands, Villa Pancha in the Dominican Republic; Giardini di Ninfa and Villa Gamberaia in Italy; La-Roseraie de L Haÿ-les-Roses, Chateau de Courances, Jardin du Luxembourg, and Jardin du Luxembourg in France. The 8 episodes explore: Roses \& Rose Gardens, Formal Gardens, Tulips and Spring Bulbs, Country Gardens Japanese Gardens Flower Gardens, Tropical Gardens, Public Gardens and Trees. Each episode presents a different garden theme as well as broader concepts of aesthetic, botanical, cultural or environmental significance.
\end{abstract}

Key words: gardens, Audrey Hepburn, students, uniuversities, foreign language.

Introduction. Actress and humanitarian Audrey Hepburn, star of "Roman Holiday" (1953, Fig. 1), "Sabrina" (1954), "The Nun's Story", "Love In The Afternoon", "The Children's Hour", "My Fair Lady" (1964), "Two For The Road", "Charade" (1963), "How to Steal a Million", "Breakfast at Tiffany's" (1961), "Wait 
Until Dark" (1967) and other, remains one of Hollywood's greatest style icons (Fig. 2) and one of the world's most successful actresses. Gardens of the World with Audrey Hepburn is her final filmed project (Fig. 3).

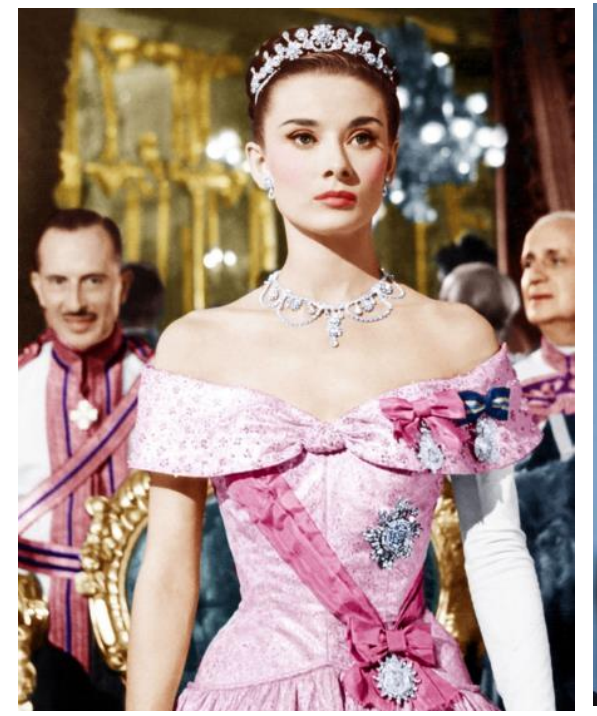

Fig. 1. Roman Holiday (1953).
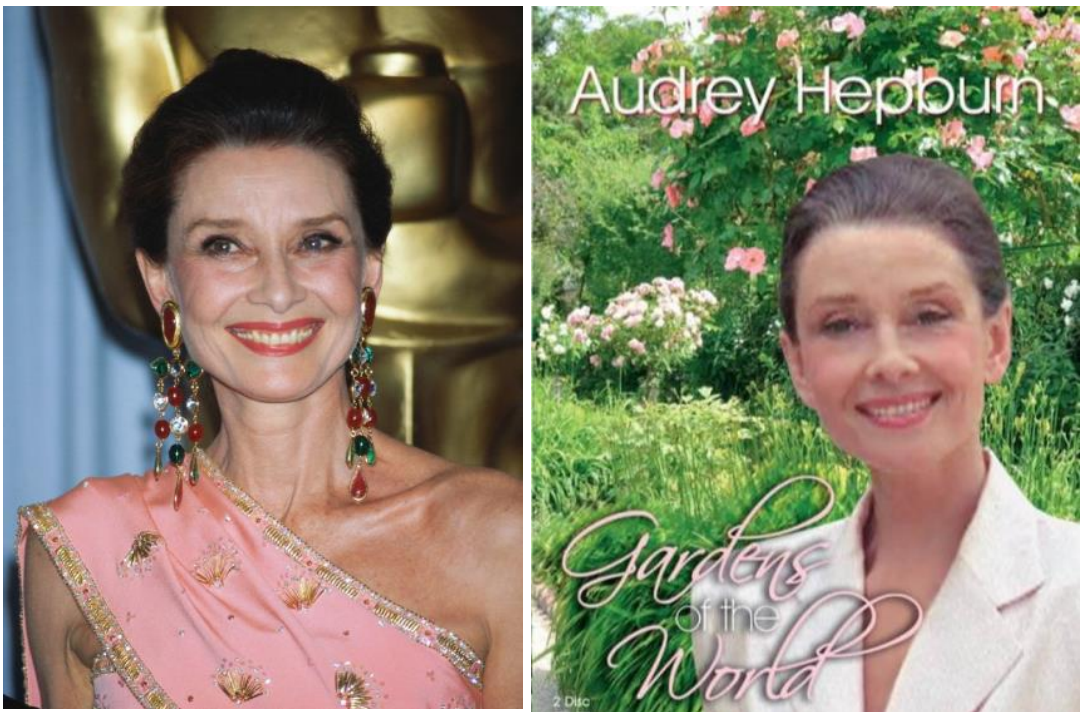

In the context of our research the formation of professional readiness of future Biology teachers has studied V. Bobrytska, A. Derkach, L. Horiana, N. Andreeva, L. Barna; some problems of the formation and development of personality in the process of preparation for professional activity and directly in its process are highlighted in the researches of L. Vygotskyi, O. Leontiev and others; using of the latest technologies and methods in teaching foreign languages for professional needs (O. Tarnopolski, S. Nikolaeva, G. Turchynova, L. Petko, V. Bezliudna, Z. Korneva).

The students at Biology department of universities can visit online many of the more famous gardens of the world with Audrey Hepburn and learn of their secrets [9; 13]. This documentary series is beautifully narrated by the elegant presence of garden lover, Audrey Hepburn. Visually lush, richly informative, refreshing, beautiful, Gardens of the World with Audrey Hepburn serves up a veritable treatise on our most illustrious cultivated environs. Each episode sets forth a different garden theme informed by broader concepts of aesthetic, historical or environmental importance, from masterful archetypes of the Italian Renaissance and 17th Century France, in Formal Gardens, to the world's first great story of urban renewal, "The Greening of Paris," in Public Gardens and Trees. All 8 episodes are wonderful and the interview 
with Audrey is a great bonus that shows us again what a special and great woman she was.

The aim of publishing papers is to present the importance of the highlyacclaimed documentary series Gardens of the World with Audrey Hepburn for the professional training of future Science teachers in the conditions of university.

The materials and the results of the research. Gardens of the World with Audrey Hepburn is a beautiful collector's series filmed on location, featuring some of the most beautiful gardens from around the world. Audrey Hepburn is as elegant as ever as she guides you on this magical journey and walks you through each of these magnificent landscapes, quoting some of her favorite authors and poets, and sharing her love and knowledge of gardens. Audrey Hepburn won an Emmy® Award for "outstanding individual achievement" in the making of this program.

Audrey Hepburn's final filmed project before her death, this gardening show is just about perfect. Magnificent gardens, fascinating historical information, Michael York's smooth and lilting narration and beautiful classical music mixed with the organic sounds of nature make this thoroughly enjoyable. But it is the moments when Ms Hepburn is on screen that are truly magical. As she gracefully walks through the landscapes and shares her love of all things horticultural with the audience.

The scene where she reads from Anne Frank's diary is just stunning (Anne Frank's diary has been translated into more than 70 languages). The chestnut tree that's been described by Anne has fallen this year, after a long struggle for survival. Audrey reads this part with so much insight, so much light, that in a way, she revives Anne's passion for life, and the tree that inspired her to write such wisdom at such a young age [8].

Audrey and Anne were two dark-haired Dutch girls who had been born in other countries. Both of these ladies were born in 1929 and have inspired countless people with their bravery; one in the written word, and the other through her emotionallycharged performances. They were less than six weeks apart in age Audrey born May 41929 (Fig. 4). and Anne, June 121929 (Fig. 6). And Anne had even known of and commented upon executions in Goirle when she wrote from the Franks' hidden 
rooms: "Prominent citizens - innocent people - are thrown into prison to await their fate. If the saboteur can't be traced, the Gestapo simply put about five hostages against the wall. Announcements of their deaths appear in the papers frequently [21]". Anne Frank wrote in her diary for two years while her family was in hiding in Amsterdam.
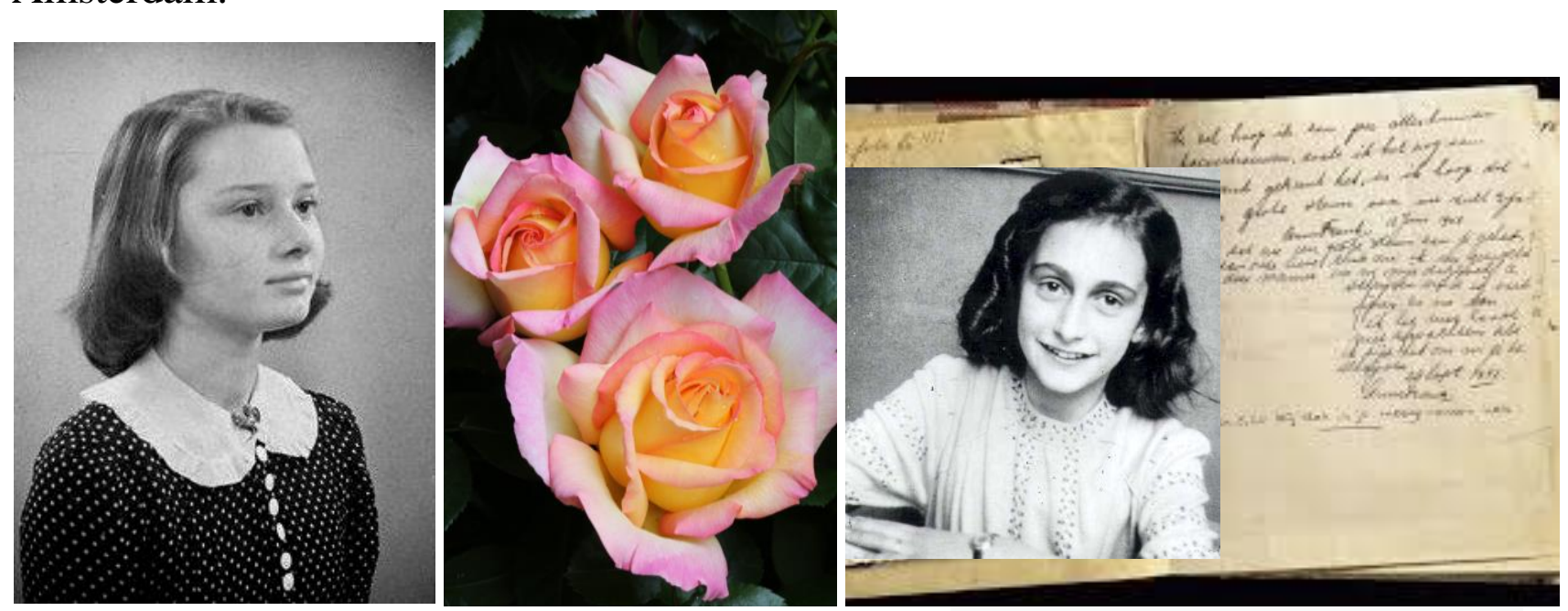

Fig. 4. Audrey Hepburn in Fig. 5. The Rose Peace (1945). Fig. 6. Anne Frank's diary1942-1944. occupied Holland (1943). Amsterdam.

Anne Frank was an ordinary teenage girl. Although she was originally from Germany, she was living in Holland when II World War broke out in 1939, as her parents had decided to leave their home country for safety reasons in 1933. In July 1942, they had to go into hiding on the top floor of a building in Amsterdam, where they lived for two years, because things were getting really difficult for Jewish families. In the summer of 1944, not long before the British, the Americans and their allies finally won the war and drove the German army away, her diary suddenly stopped. The Nazis killed Anne Frank, but luckily for everybody, they couldn't kill her memory [4], see movie [11].

Nature and flowers had special meaning for Audrey Hepburn due to the hope they brought after the World War II, assuring food was coming and reminding her to appreciate nature's beauty.

Audrey Hepburn became a fashion and cultural icon, and continues to be so today. She was also a magnificent humanitarian [6]. The memories of World War II horrors shaped her desire to help children and she became a goodwill ambassador for 
UNICEF in the late 1980s. Traveling the world, Hepburn tried to raise awareness about children in need. She understood too well what it was like to go hungry from her days in the Netherlands during the German Occupation. Making more than 50 trips, Hepburn visited UNICEF projects in Asia, Africa and Central and South America. She won a special Academy Award for her humanitarian work in 1993.

Marking the 70th anniversary of the United Nations' Universal Declaration of Human Rights, experience music that celebrates the triumph of the human spirit. Hear Grammy Award-winning mezzo-soprano Isabel Leonard narrate Michael Tilson Thomas' spellbinding musical setting From the Diary of Anne Frank, a piece written for Audrey Hepburn and UNICEF in 1990 [7]. Performance of "Elegy for Anne Frank" by Lukas Foss at The Oslo Concert [15], arranged in 1990 by Eli Wiesel Nobel Peace Prize Lauriate 1986. Audrey Hepburn's reciting from "The Diary of Anne Frank" starts at 5.12 [7].

Hepburn's first field mission for UNICEF was to Ethiopia in 1988 (Fig. 7, 9). She visited an orphanage in Mek'ele that housed 500 starving children and had UNICEF send food [5].

The United States President George Bush presented Hepburn with the Presidential Medal of Freedom (see video [10]) (Fig. 8) in recognition of her work with UNICEF, and the Academy of Motion Picture Arts and Sciences posthumously awarded her the Jean Hersholt Humanitarian Award for her contribution to humanity. Unfortunately, due to severe illness, Audrey Hepburn was unable to attend the medal ceremony.

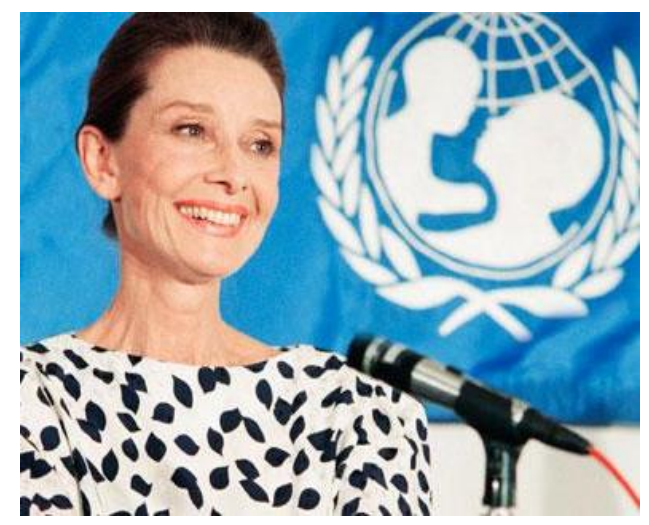

Fig. 7. Ambassador of UNICEF

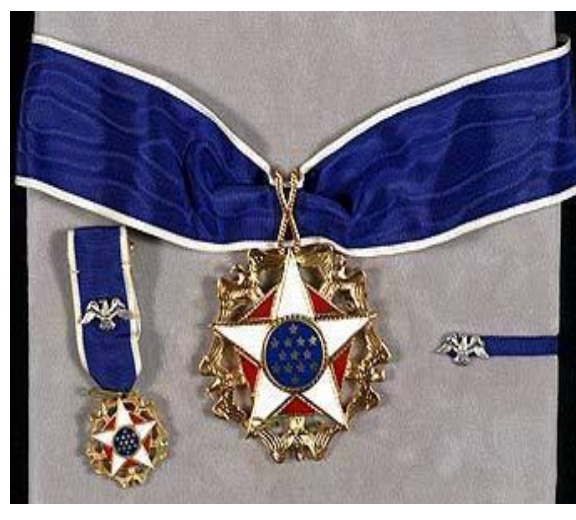

Fig. 8. Presidential Medal of Freedom.

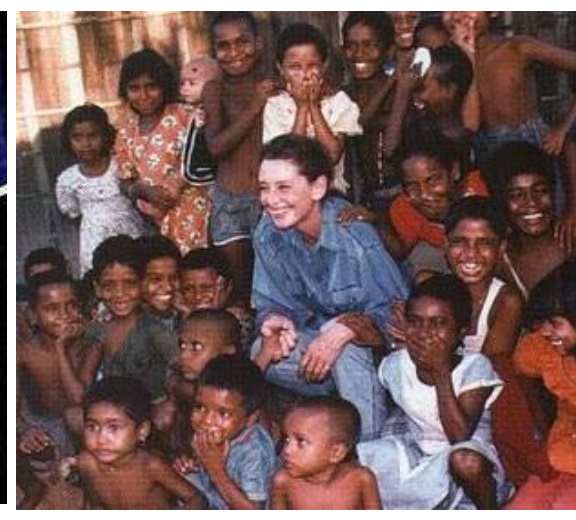

Fig. 9. Audrey Hepburn in Ethiopia. 
By the way Gardens of the World with Audrey Hepburn is an acclaimed documentary television series that debuted in the United States on PBS on January 21, 1993, filmed on location in seven countries in the spring and summer of 1990. Hepburn was awarded an Emmy for Outstanding Individual Achievement posthumously. The series features Hepburn visiting exemplary and elegant gardens both private and public; each episode sets forth a different garden theme, as well as aesthetic, environmental, historical or horticultural concepts. Interspersed with Hepburn's on-camera performances are expository and historical background segments narrated both by Audrey Hepburn and Michael York [12].

These are: Episode 1. "Roses and Rose Gardens": An adventure with the flower of legend, romance and beauty (see video [9]). Episode 2. "Formal Gardens": A journey through the evolution of formal garden design. Episode 3. "Country Gardens": An exploration of the earthly country garden. Episode 4. "Public Gardens and Trees": The stories of Mt. Vernon and the greening of Paris, concluding with Hepburn's tribute to trees and nature. Episode 5. "Flower Gardens": An exploration of Monet's gardens at Giverny and classic English perennial border styles. Episode 6. "Tropical Gardens": A wide ranging affirmation of nature's floral diversity. Episode 7. "Japanese Gardens": A journey reflecting centuries of Japanese cultural reverence for nature. Episode 8. "Tulips and Spring Bulbs": A focus on spring blossoms and their inspiration as art and in the garden. Some of the gardens featured in the show include: Claude Monet's gardens at Giverny, George Washington's estate at Mount Vernon, and Jardin du Luxembourg in Paris [12].

Back to studying gardens of the world. Episode 1. "Roses and Rose Gardens" [9].

A rose garden or rosarium is a garden or park, often open to the public, used to present and grow various types of garden roses or rose species. Designs vary tremendously and roses may be displayed alongside other plants or grouped by individual variety, colour or class in rose beds [35].

A rose is a woody perennial flowering plant of the genus Rosa, in the family Rosaceae, or the flower it bears. There are over three hundred species and tens of tens thousands of cultivars. They form a group of plants that can be erect shrubs, climbing, 
or trailing, with stems that are often armed with sharp prickles. The name rose comes from French, itself from Latin rosa [34].

Episode 1 (Fig. 12) Miss Audrey Hepburn's opening:

Dear rose, thy joy's undimmed,

Thy cup is ruby-rimmed,

Thy cup's heart nectar-brimmed [9].

It's poem "Women and Roses" by Robert Browning (1812-1889), Fig. 10, 11. He was an eminent British poet of the Victorian period. He is also classified among outstanding Romantics, such as, Wordsworth, Shelley, Keats and so on [33].

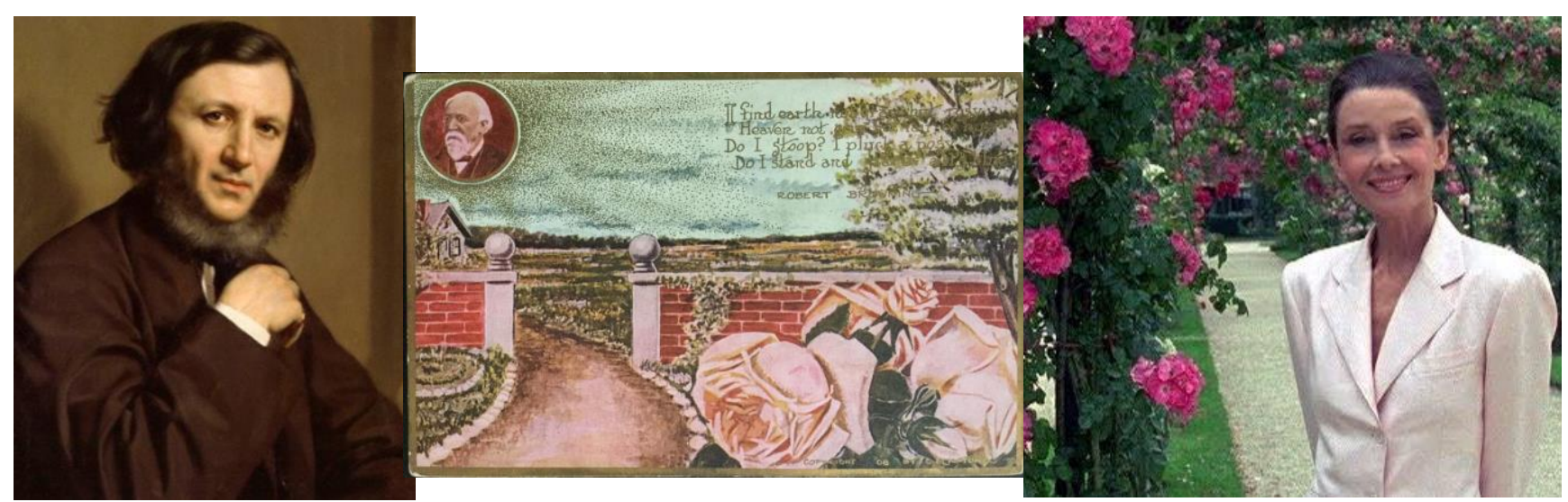

Fig. 10. Robert Browning. Fig. 11. Poem "Women and Roses".

Fig. 12. Episod 1 [14].

Audrey Hepburn leads an eloquent adventure in pursuit of the breadth and beauty of the rose: old roses, modern roses, wild roses; floribundas, climbers, and ramblers; Bourbons, Damasks, Gallicas [22] and Hybrid Teas. From the French ideal of a rose garden south of Paris at La Roseraie de l'Hays les Roses (La Roseraie du Val-de-Marne, see video [49], Fig. 13, 14) to the unsurpassed collection and allure of

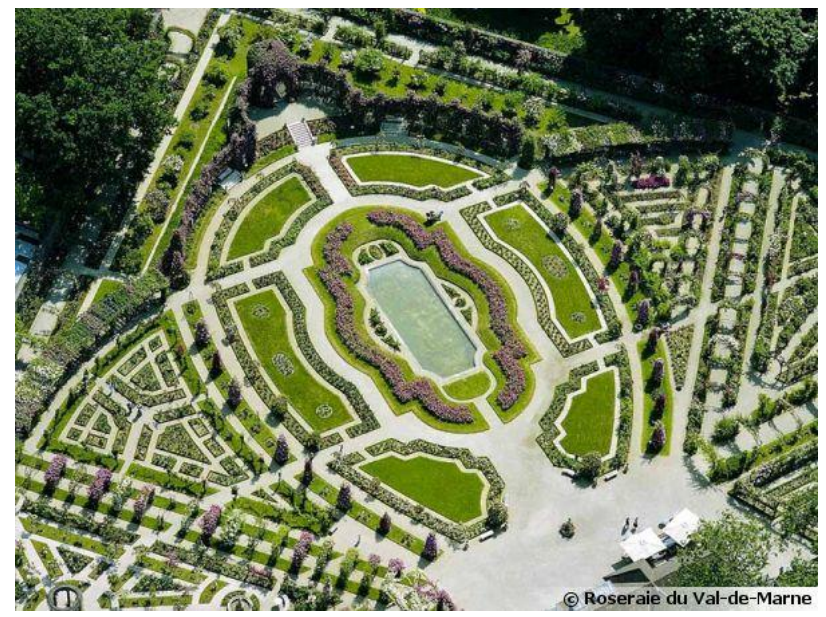

Fig. 13. Roseraie du Val de Marne, Paris.

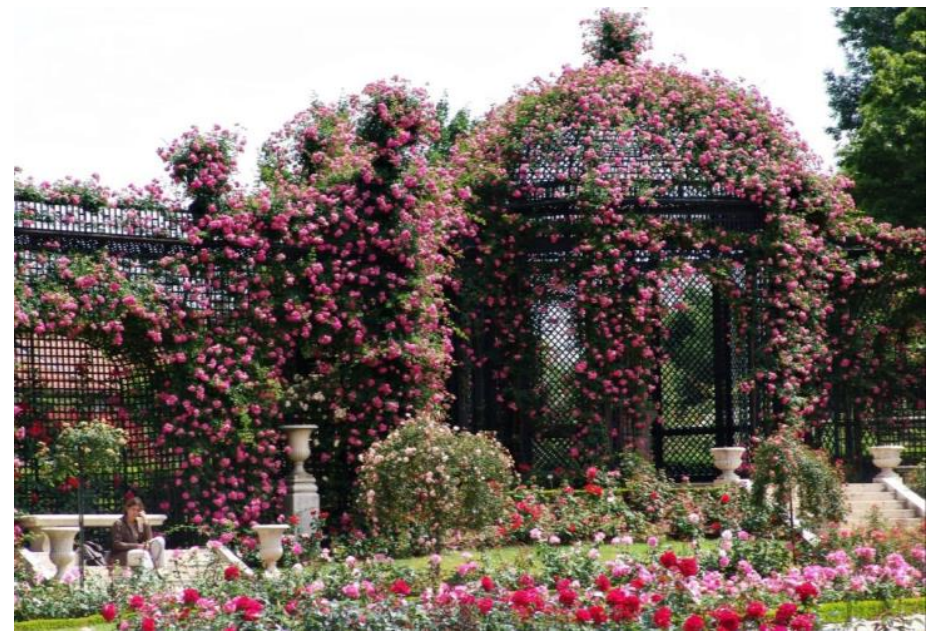

Fig. 14. Roseraie du Val de Marne. Dome.

old roses duringhigh rose tide at Mottisfont Abbey in Hampshire, England (Fig. 15, 19, 20), the rose affirms its rightful place as the ultimate flower of legend, romance 
and beauty. Appearing with Audrey Hepburn: Sir Graham Stuart Thomas (Fig. 16), one of the 20th century's greatest rosarians and author of world renown [36].
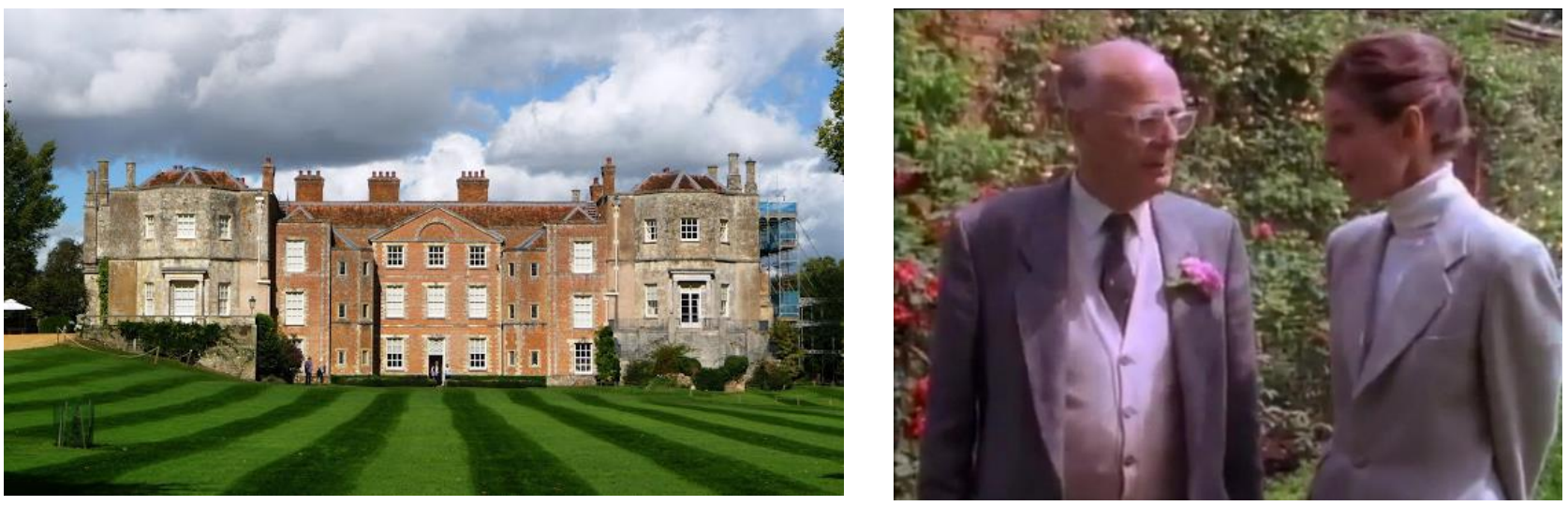

Fig. 15. Mottisfont Abbey in Hampshire, England. Fig. 16. With Sir Graham Stuart Thomas.

Mottisfont Abbey's walled garden has been home to the National Collection of old-fashioned roses since the 1970's when world-famous rosarian Graham Stuart Thomas (who has a yellow David Austin rose named after him, Fig. 18), re-designed the former kitchen garden at this former Augustinian abbey for the National Trust.

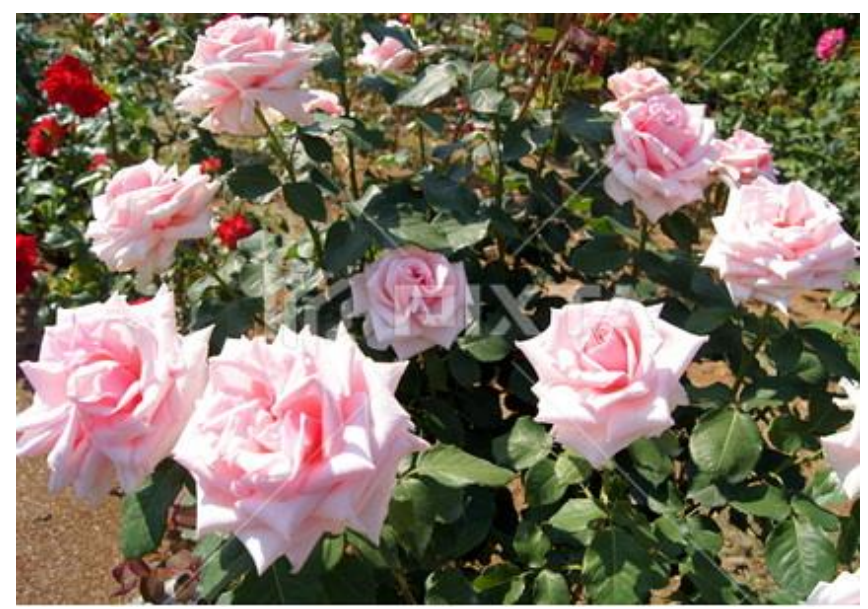

Fig. 17. Audrey Hepburn roses by breeder Jerry Twomey.

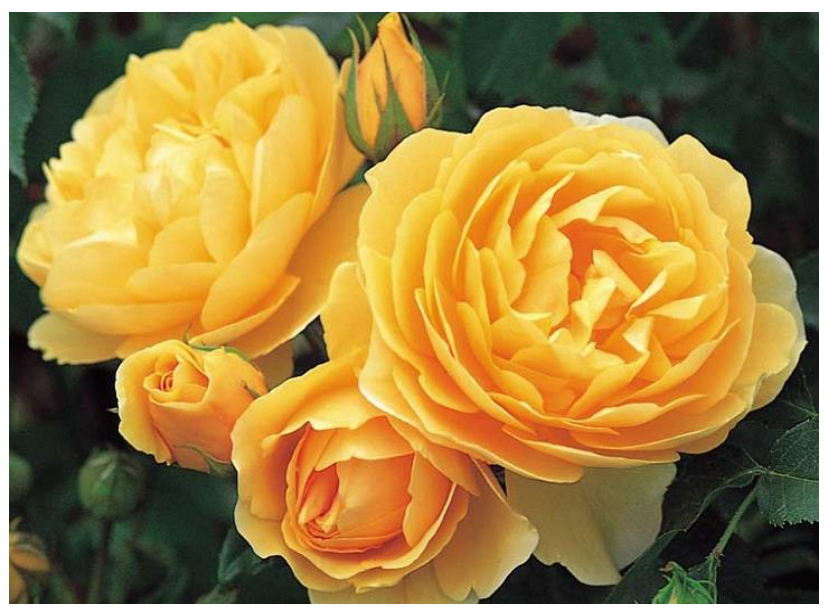

Fig. 18. Rosa Graham Thomas.

Four decades later, the rose garden is one of the most famous in the world and draws visitors from far and wide to marvel at the wonderfully scented garden.

The collection of roses is quite breathtaking.

The Abbey, which dates in part to the 13th century provides a striking backdrop to a 21-acre garden -designed in part by Sir Geoffrey Jellicoe. [37].

Set by the banks of the crystal River Test, cutting through the chalk downland, sits Mottisfont Priory, dating to the 13th Century and with a colourful history right up to the 20th Century with Maud and Gilbert Russell bringing life again to the old 
house and the National Trust subsequently taking the House and Gardens into its care - and particularly honouring its rose heritage [20].

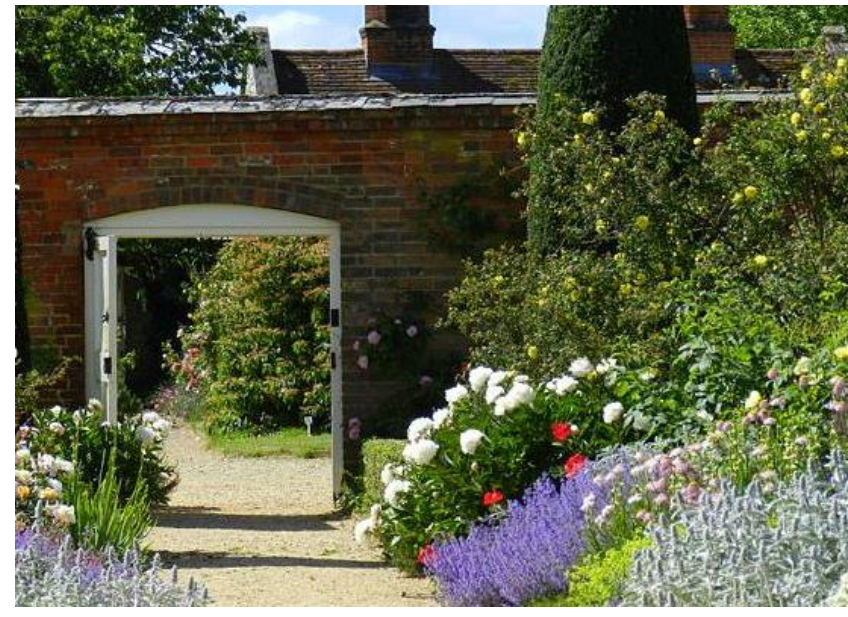

Fig. 19. Entrance to the walled garden.

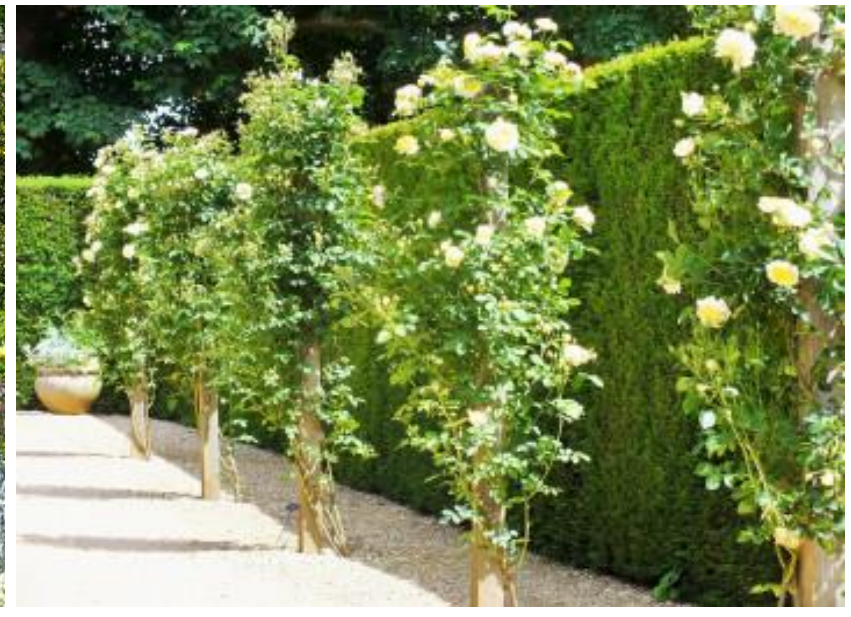

Fig. 20. The Pilgrim.

Audrey Hepburn ends "Roses and Rose Gardens" with words from song "A Red, Red Rose" (1794) in Scots by Robert Burns (video at 20.06 min [9]:

O my Luve's like a red, red rose

That's newly sprung in june;

O my Luve's like the melodie

That's sweetly play'd in tune... [1].

Our students can sing and listen to an old romantic ballad written by Scotland's National Poet, Robert Burns (1759-1796, Fig. 21, 22), sung and played by Josienne Clarke and Ben Walker [38].

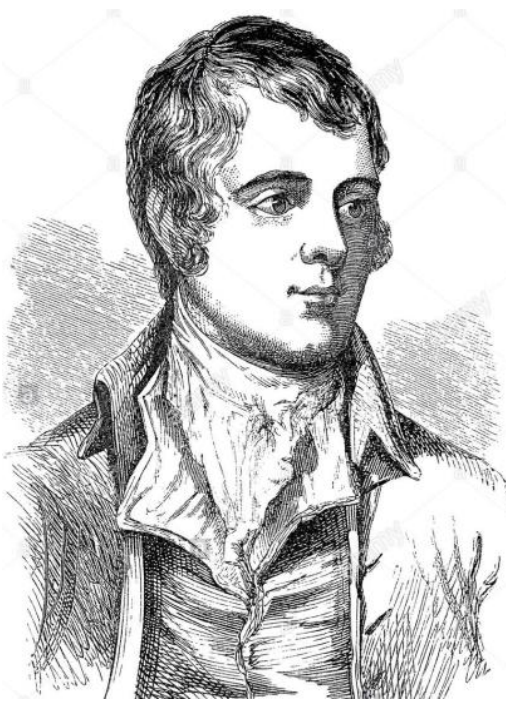

Fig. 21 Robert Burns.
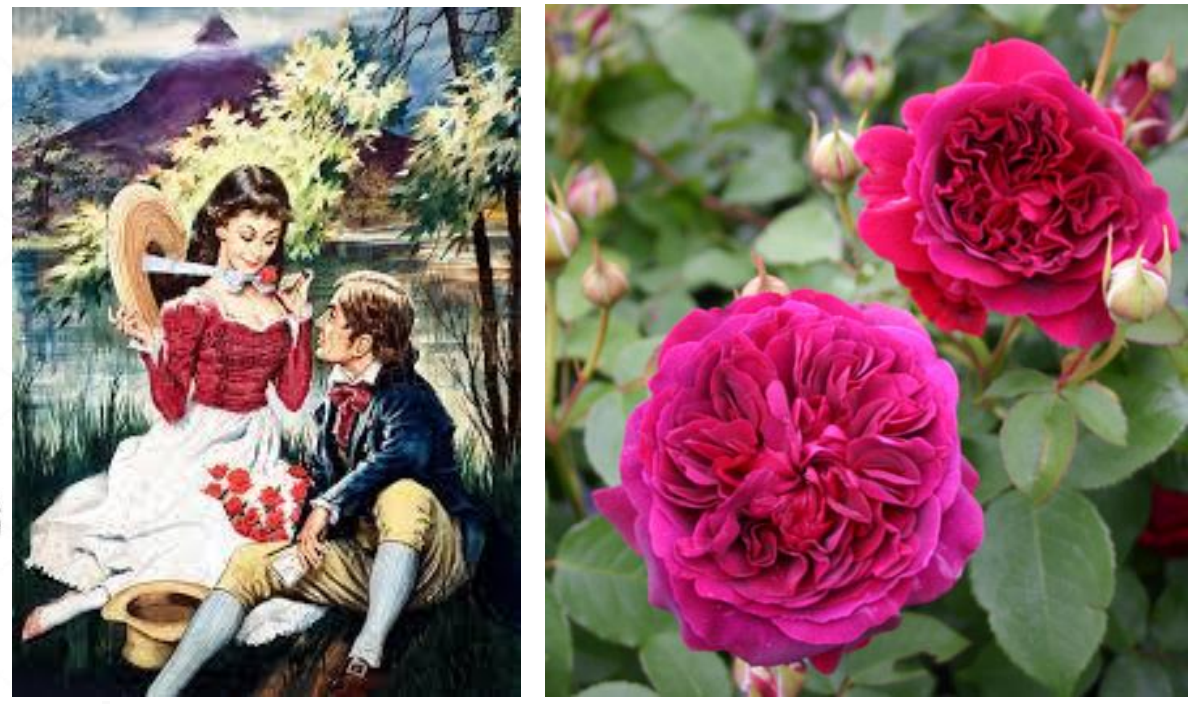

Fig. 22. A Red, Red Rose illustration, 1962. Fig. 23. William Shakespeare 2000. 
Getting to the point for the students of our Faculty Faculty of Science Education and Ecology the film "Roses and Rose Gardens" [9] is valuable because the students of scientific problem group have been studyng for 3 years the famous rosaries of the world and the selection work of their headbreeders (D. Austin, F. Meilland, G. Thomas, J. Twomey). The results were published at conferences as scientific and practical publications by students with supervisors, e.g., "The English "William and Catherine" Rose and Wedding of The Century" [19], "The image of British actress Audrey Hepburn in a rose named after "most beautiful woman of all time" [23], " The rose "Leonardo da Vinci" by Alain Mayland" [16], "Rosa "Sir Walter Scott Rose" by David Austin" [30], "Great Rosarian of the World' - British hybridizer of English Garden roses David Austin" [14], "The Wild Prairie Rose: official State Flower of North Dakota and Iowa" [31], "Rose: America's National Flower" [29], "The William Shakespeare Rose and the Rose in Shakespeare's works" [32], "William Shakespeare rose named after 'British Man of the Millennium' [40], "The rose Sweet Juliet is a tribute to young love" [41], "Wuthering Heights and rose Emily Brontë named after celebrating the bicentenary of the birth of the novelist" [18], "David Austin English Shrub Rose "Kew Gardens" [22], "Charles Darwin. English Shrub Rose bred by David Austin" [39].

R. J. Sternberg notes that creativity of personality, which can lead to new scientific discoveries, involves intellectual abilities, knowledge, and motivation, as does problem solving. But, he posits that creativity also requires the disposition or preference for engaging in novel ways of thinking [43; 44]. He characterizes these dispositions as "thinking styles" [42]. Thinking styles describes individual differences not in abilities, but in preferences for the use of our abilities. He claims that matching learners' thinking styles to their learning environment can enhance creative thinking and problem solving.

Americans scientists Eric M. Anderman and Gale M. Sinatra dwell on scientific problems of import require non-routine problem solving. That is, most problems worth solving are ill-structured and required "thinking outside the box" for an effective solution strategy. In general, successful problem solving requires 
domainspecific knowledge and skills (Chi \& Glaser, 1985) and the procedural and conditional knowledge to know when and how to apply those skills (Paris, Lipson, \& Wixson, 1983). Non-routine problem solving requires the ability to metacognitively monitor and selfregulate relevant skills and strategies. In addition, effective problem solvers also need the "will" (the motivational goals, attitudes, and interests) to attend to the problem and persist in the face of difficulties [3, p. 11].

Conclusion. We would to tell that Audrey Hepburn was a wonderful woman, mother, actress, presenter, ambassador of UNICEF. She did not consider herself ideal, but she was considered an icon of style. Her elegance and style will always be remembered in film history as evidenced by her being named in Empire magazine's «The Top 100 Movie Stars of All Time».

The last work by Audrey Hepburn in kinoindustry "Gardens of the World with Audrey Hepburn" is important for the training of Science students in the conditions of university.

Most important, we are at a critical point in terms of encouraging students to consider careers in Science. Many Ukrainian jobs are being shipped overseas to highly qualified individuals who are well trained in science. Many Ukrainian students turn away from science-related disciplines because they have had bad experiences in science classes during high school.

Much research in recent years has indicated that science classrooms can be created in ways that enhance the cognitive abilities of students. Lecturers can have profound effects on students' cognition and motivation as they attend to daily, routine issues. The specific decisions that future Science teachers make can affect a number of important educational outcomes.

\section{References}

1. A Red, Red Rose. URI : https://en.wikipedia.org/wiki/A_Red,_Red_Rose

2. A Red, Red Rose by Robert Burns (read by Tom O'Bedlam). URI : https://www.youtube.com/watch?v=xhl-KHkzPfY

3. Anderman Eric M., Sinatra Gale M., The Challenges of Teaching and Learning about Science in the 21st Century: Exploring the Abilities and Constraints of Adolescent Learners / Paper Commissioned by the National Academy of Education. $50 \mathrm{p}$.

URI : https://sites.nationalacademies.org/cs/groups/dbassesite/documents/webpage/dbasse_07 2608.pdf 
4. Anne Frank. URI : https://sites.google.com/site/darksides4eso/anne-frank

5. Audrey Hepburn URI: https://www.britannica.com/biography/Audrey-Hepburn

6. Audrey Hepburn. Biography. URI : https://www.biography.com/actor/audrey-hepburn

7. Audrey Hepburn et al in "Elegy for Anne Frank" (Lukas Foss) - 1990. URI : https://www.youtube.com/watch?v=JbmkSAODShQ

8. Audrey Hepburn journal Anne Erank. https://www.youtube.com/watch?v=OJj5RoLAhzw

9. Audrey Hepburn - Gardens of The World: Roses and Rose Gardens. URI : https://www.youtube.com/watch?v=bkGx6Ur3ToI

10. Audrey Hepburn Receiving the Medal URI: https://www.cspan.org/video/?c4533162/user-clip-audrey-hepburn-receiving-medal

11. Diary of Anne Frank (Das Tagebuch der Anne Frank), 2016 Germany, Dir. Hans Steinbichler. URI: http://baskino.me/films/dramy/14687-dnevnik-anny-frank.html

12. Gardens of the World with Audrey Hepburn. URI : https://en.wikipedia.org/wiki/Gardens_of_the_World_with_Audrey_Hepburn

13. Gardens of the World with Audrey Hepburn. Trailer. URI : https://eatlovesavor.com/gardens-of-the-world-with-audrey-hepburn/

14. Haladiy B. 'Great Rosarian of the World' - British hybridizer of English Garden roses David Austin / B. Haladiy, L. Pet'ko // Topical aspects of modern science and practice : I International Scientific and Practical Conference (Frankfurt am Main, 21-24 September 2020). Germany, 2020. Pp. 45-50.

15. Hatets anatomi. - Konsert (Oslo, 28.08.1990). Oslo Filharmoniske Orkester. Andre Audrey Hepburn, Gregory Peck, Frederica von Stade, James Galway, Elie Wiesel, Vaclav Havel og Chai Ling. Fra Oslo Konserthus. URI : https://tv.nrk.no/program/FNYH70004790

16. Holovko T., Pet'ko L., Turchynova G. The rose "Leonardo da Vinci" by Alain Mayland // About the problems of science and practice, tasks and ways to solve them : abstracts of VI International scientific-practical conference (Milan, 26-28 October 2020). - Milan, Italy : International Science Group, 2020. Pp. 51-59.

17. Jules Gravereaux. URI : https://en.wikipedia.org/wiki/Jules_Gravereaux

18. Kotliarova O., Pet'ko L. 'Wuthering Heights' and rose 'Emily Brontë' named after celebrating the bicentenary of the birth of the novelist // Current issues of science: materials of the first international scientific practice. Internet conferences (Berdyansk, April 30, 2020). Berdyansk: BSPU, 2020. Pp. 8-17. (in Ukrainian)

19. Klymenko N., Pet'ko L. The image of British actress Audrey Hepburn in a rose named after "most beautiful woman of all time". Topical Issues of Science and Practice : abstracts of VII Sientific and Practical Conference (London, 02-06 November 2020). Great Britain, London : International Science Group, 2020. 781 p. Pp. 42-51.

20. Mottisfont Abbey - a look back at the rose gardens in June 2014 (It's raining again in 2016). URI : https://teddingtongardener.com/2016/07/12/mottisfont-abbey-a-look-back-at-therose-gardens-in-june-2014-its-raining-again-in-2016/

21. Mudie Keir. The reason why Hollywood star Audrey Hepburn was haunted by Anne Frank's story. Mirror. 1 Nov. 2020. URI : https://www.mirror.co.uk/3am/celebritynews/reason-hollywood-star-audrey-hepburn-22940631 
22. Oleshchenko M., Pet'ko L. David Austin English bush rose "Kew Gardens" //Basic and applied research: current issues, achievements and innovations: materials of the I international scientific-practical Internet conference (Berdyansk, March 27, 2020). Berdyansk. 2020. Pp. 13-19. (in Ukrainian)

23. Ostapchuk A., Pet'ko L., Turchynova G. The English "William and Catherine" Rose and Wedding of The Century. Topical Issues of Science and Practice : abstracts of VII Sientific and Practical Conference (London, 02-06 November 2020). Great Britain, London : International Science Group, 2020. 781 p. Pp. 52-63.

24. Pet'ko Lyudmila. Developing students' creativity in conditions of university // Research: tendencies and prospects: Collection of scientific articles. - Editorial Arane, S.A. de C.V., Mexico City, Mexico, 2017. Pp. 272-276.

25. Pet'ko L. V. Development of students' cognitive activity in foreign language teaching by using analogy method // Actual problems of globalization: Collection of scientific articles. - Midas S.A., Thessaloniki, Greece, 2016. Pp. 232-237.

26. Pet'ko L. The development of student youth aesthetic culture on professional direction // Topical issues of contemporary science: Collection of scientific articles. - C.E.I.M., Valencia, Venezuela, 2017.

27. Pet'ko L. Multicultural upbringing of students and the formation of professionally oriented foreign language teaching environment // Perspectives of research and development : Collection of scientific articles. SAUL Publishing Ltd, Dublin, Ireland, 2017. Pp. 164-170.

28. Pet'ko L. V. Teaching methods and the formation of professionally oriented foreign language learning environment in conditions of university. Intellectual Archive. 2016. Vol. 5. No. 4 (July/August). Toronto : Shiny Word Corp., Canada. Pp. 73-87.

29. Pet'ko L., Faut M. Rose: America's National Flower // Current Trends in the Development of Science and Practice: papers of the $\mathrm{XXI}^{\text {th }}$ International scientific and practical conference (15-16 June, 2020). Haifa, Israel. Publisher: International Science Groupe. 2020. Pp. 48-54.

30. Pet'ko L., Turchynova G., Bova K. Rosa "Sir Walter Scott Rose" by David Austin // Integration of scientific bases into practice: abstracts of IV International Scientific and Practical Conference (Stockholm, 12-16 October 2020 p.), Stockholm, Sweden : International Science Group, 2020. 523 p. Pp. 33-41.

31. Pet'ko L., Turchynova G., Faut M. The Wild Prairie Rose : official State Flower of North Dakota and Iowa. // Theoretical Foundations for the Implementation And Adaptation of Scientific Achievements in Practice : papers of the XXIInd International scientific and practical conference (22-23 June, 2020). Helsinki, Finland. Publisher : International Science Groupe, 2020.Pp. 106-114.

32. Pet'ko L., Turchynova G., Sokolov T. The William Shakespeare Rose and the Rose in Shakespeare's works // Impact of modernity on science and practice: Abstracts of XVIII International Scientific and Practical Conference. Boston, USA 2020. Pp. 116-125.

33. Robert Browning's 200th Birth Anniversary. URI : https://kochiread.blogspot.com/2012/09/robert-brownings-200th-birth.html

34. Rose. URI : https://en.wikipedia.org/wiki/Rose

35. Rose Garden. URI : https://en.wikipedia.org/wiki/Rose_garden

36. Roses \& Rose Gardens. Episode One. URI : https://www.artfilms.com.au/item/rosesand-rose-gardens-episode-one 
37. See some of the best roses in Britain at Mottisfont Abbey. URI : http://thegallopinggardener.blogspot.com/2011/05/make-date-with-mottisfont-rose-garden.html

38. Scottish Music - My Love Is Like A Red Red Rose. URI : https://www.youtube.com/watch?v=QK9WK0QhejA

39. Sharpilo D. Charles Darwin. English Shrub Rose bred by David Austin / D. Sharpilo, L. Pet'ko // Basic and applied research: current issues, achievements and innovations: materials of the first international scientific-practical Internet conference (Berdyansk, March 27, 2020). Berdyansk: BSPU, 2020. Pp. 30-36.

40. Shevchenko V., Pet'ko L. William Shakespeare rose named after 'British Man of the Millennium' // Fundamental and applied scientific research: current issues, achievements and innovations: materials of the first international scientific-practical Internet conference (sity Berdyansk, March 27, 2020). Berdyansk. 2020. 150 c. Pp. 37-44. (in Ukrainian)

41. Stepanchenko D., Pet'ko L. The rose Sweet Juliet is a tribute to young love // Current issues of science: materials and international scientific practice. Internet conference (Berdyansk, April 30, 2020). Berdyansk: BSPU, 2020. 202 p. Pp. 36-46. URI: http://enpuir.npu.edu.ua/handle/123456789/28862 (in Ukrainian)

42. Sternberg R. J. Thinking Styles. New York, NY: Cambridge University Press. 1997.

43. Sternberg R. J. Handbook of Creativity. New York, NY: Cambridge University Press. 1999.

44. Sternberg, R. J. The nature of creativity. Creativity Research Journal, 2006. 18(1), pp. $87-98$.

45. Turchynova Ganna. Training Teachers of Natural Sciences in the Context of the New Ukrainian School // Education, Law, Business: Collection of scientific articles. - Cartero Publishing House, Madrid, Spain, 2019. - 200 p. P. 175-178.

46. Turchinova G.V Preparation of future teachers of natural sciences for research activities in the process of learning a foreign language in the specialty / G.V. Turchynova // Actual problems of education: Collective monograph. Pegasus Publishing, Lisbon, Portugal, 2018. Pp. 70-84. (in Ukrainian)

URI http://enpuir.npu.edu.ua/handle/123456789/21238

47. Turchynova GV Foreign language training of future teachers of natural sciences in the world of the concept of the New Ukrainian school // Current issues of pedagogy: Collective monograph. - Edizioni Magi, Roma, Italy. 2019. Pp. 4-30. URI: http://enpuir.npu.edu.ua/handle/123456789/26904 (in Ukrainian)

48. Turchynova G., Alieksieienko T., Karaman S., Kushniruk S., Hladun T. Simulation of a Cloud Oriented Learning Environment at an Educational Establishment. The 36th IBIMA Conference (Granada, Spain, 4-5 November, 2020).

49. Val-de-Marne Rose Garden. URI : https://www.youtube.com/watch?v=R_uz22wdUjA

50. Webb Ali. The story behind the Audrey Hepburn tulip. URI :

https://www.crfashionbook.com/celebrity/a20065493/audrey-hepburn-namesake-tulip-storynetherlands/\#: :text=According\%20to\%20the\%20Netherlands\%20Flowerbulb,extensive $\% 20$ charita ble\%20work\%20for\%20UNICEF.

51. Zapruder Alexandra. A choir of voices: Holocaust diaries by Anne Frank and other young writers. URI : https://www.annefrank.org/en/anne-frank/go-in-depth/holocaust-diaries-annefrank-and-other-young-writer/ 